\title{
INITIAL SCREENING OF THERMOCHEMICAL WATER-SPLITTING CYCLES FOR HIGH EFFICIENCY GENERATION OF HYDROGEN FUELS USING NUCLEAR POWER
}

by
L.C. BROWN, J.F. FUNK, ${ }^{\star}$ and S.K. SHOWALTER ${ }^{\dagger}$

*University of Kentucky, Lexington, Kentucky.

†Sandia National Laboratories, Albuquerque, New Mexico.

Work supported by the Nuclear Energy Research Initiative (NERI) under Grant No. DE-FG03-99SF21888 and the U.S. Department of Energy under Contract No. DE-AC04-94AL85000

GA PROJECT 30047 APRIL 2000 


\section{DISCLAIMER}

This report was prepared as an account of work sponsored by an agency of the United States Government. Neither the United States Government nor any agency thereof, nor any of their employees, make any warranty, express or implied, or assumes any legal liability or responsibility for the accuracy, completeness, or usefulness of any information, apparatus, product, or process disclosed, or represents that its use would not infringe privately owned rights. Reference herein to any specific commercial product, process, or service by trade name, trademark, manufacturer, or otherwise does not necessarily constitute or imply its endorsement, recommendation, or favoring by the United States Government or any agency thereof. The views and opinions of authors expressed herein do not necessarily state or reflect those of the United States Government or any agency thereof. 


\section{DISCLAIMER}

Portions of this document may be illegible in electronic image products. Images are produced from the best available original document. 


\section{EXECUTIVE SUMMARY}

There is currently no large scale, cost-effective, environmentally attractive hydrogen production process, nor is such a process available for commercialization. Hydrogen is a promising energy carrier, which potentially could replace the fossil fuels used in the transportation sector of our economy. Fossil fuels are polluting and carbon dioxide emissions from their combustion are thought to be responsible for global warming.

The purpose of this work is to determine the potential for efficient, cost-effective, large-scale production of hydrogen utilizing high temperature heat from an advanced nuclear power station. Almost 800 literature references were located which pertain to thermochemical production of hydrogen from water and over 100 thermochemical watersplitting cycles were examined. Using defined criteria and quantifiable metrics, 25 cycles have been selected for more detailed study. 
,

. 


\section{INTRODUCTION}

Combustion of fossil fuels, used to generate electricity and power transportation, provides $86 \%$ of the world's energy. Drawbacks to fossil fuel utilization include limited supply, pollution and carbon dioxide emissions. Carbon dioxide emissions, thought to be responsible for global warming, are now the subject of international treaties. Together these argue for the replacement of fossil fuels with nuclear energy. Conventional nuclear plants readily generate electric power but fossil fuels are firmly entrenched in the transportation sector. Hydrogen is an environmentally attractive transportation fuel that has the potential to displace fossil fuels. Hydrogen will be particularly advantageous when coupled with fuel cells. Contemporary hydrogen production is primarily based on fossil fuels and most specifically on natural gas. When hydrogen is produced using energy derived from fossil fuels, there is little or no environmental advantage.

There is currently no large scale, cost-effective, environmentally attractive hydrogen production process, nor is such a process available for commercialization. The objective of this work is to define an economically feasible process for the production of hydrogen, by nuclear means, using an advanced high-temperature nuclear reactor as the energy source. Hydrogen production by thermochemical water-splitting, a chemical process that accomplishes the decomposition of water into hydrogen and oxygen using only heat or, in the case of a hybrid thermochemical process, by a combination of heat and electrolysis, meets these goals. In addition, hydrogen produced from fossil fuels has trace contaminants that are detrimental to fuel cells. Thermochemical hydrogen will not contain these contaminants. Electrolysis, the alternative process for producing hydrogen using nuclear energy, suffers from thermodynamic inefficiencies in both the electrical production and electrolytic parts of the process. The efficiency of electrolysis is currently is about $70 \%$. Electric power generation efficiency would have to exceed $74 \%$ for the combined efficiency to exceed the $52 \%$ calculated for one thermochemical cycle.

Thermochemical water-splitting cycles have been known for the past 35 years. They were extensively studied in the late 70 s and early 80 s but have been substantially neglected in the past 10 years, particularly in the U.S. While there is no question about the technical feasibility and the potential for high efficiency, cycles with proven low cost 
and high efficiency have yet to be developed commercially. Over one hundred cycles have been proposed, but substantial research has been executed on only a few.

In this work, an exhaustive literature search was performed to locate all cycles previously proposed. The cycles located have been screened using objective criteria, to determine which can benefit, in terms of efficiency and cost, from the high-temperature capabilities of advanced nuclear reactors. The literature search, the development of the screening criteria, the screening process and the results will be described in the following sections. Subsequently, the cycles will be analyzed as to their adaptability to advanced high-temperature nuclear reactors, considering among other things, the latest improvements in materials of construction and new membrane separation technologies. Guided by the results of the secondary screening process, one cycle will be selected for integration into the advanced nuclear reactor system. The required flowsheets will be developed and preliminary engineering estimates of size and cost will be made for major pieces of equipment. From this information, a preliminary estimate of efficiency and cost will be made. 


\section{PROJECT DATABASES}

An important part of the preliminary screening effort dealt with the details of organizing and presenting data in a easy to use form, i.e., the organization of project specific databases. There are many sources of compiled literature data. Each database uses its own method of organizing and presenting the same generic type of data. This makes it important that the data from the various sources be translated into a common format for comparison and duplicate removal. EndNote [1], a widely accepted and readily available database program designed to manage bibliographic information, is used to maintain the project literature database. EndNote provides the tools required for translating the output data from any of the various literature database search engines into a common format. Each EndNote entry includes the bibliographic entry, tracking information and, if available, an abstract.

A second database was required to keep track of all the cycles. Here we had three main goals:

1. Inclusion of all the information required to screen the cycles

2. Ability to search for common threads among the various cycles and display the data in alternative ways

3. A means of preventing the same cycle from being entered multiple times.

Together, these indicated that we needed a relational database: we selected MS Access 2000 as the tool with which to organize the cycle data.

Figure 1 indicates the organization of the cycle database. There are four main data table areas within the database: general, reactions, authors and references. Each of these tables was linked with a junction field that allowed a one-to-many relationship linked back to the general table. This allowed for a reference or reaction that was linked to multiple cycles to be represented only once in the database. The cycles were all uniquely identified by a primary identification number. Names were assigned to ease reference in discussion when ranking the cycles. The names associated with the cycles were created from either given names in the references or names created from the compounds used in the cycle. This database format makes it easy to search for commonality between various 


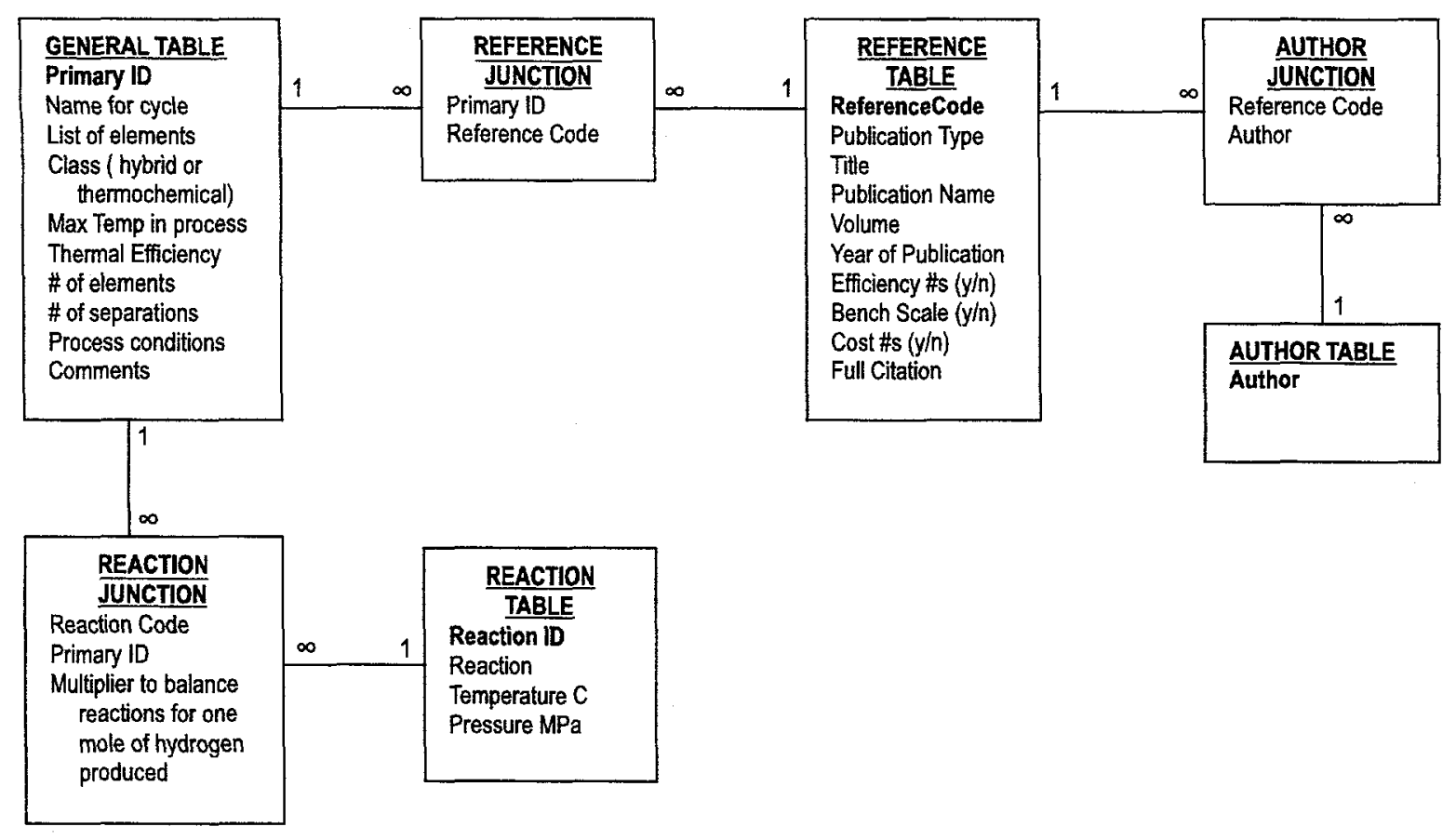

Fig. 1. Project Database Structure.

cycles. The cycle database contains the details of the chemical reactions and process conditions for the process, as well as the abbreviated bibliographic information literature references that describe or refer to the cycles. Rules were developed for addition of reactions to the database so that repetition could be easily identified. All reactants and products were arranged in alphabetical order with $\mathrm{H}_{2}, \mathrm{H}_{2} \mathrm{O}$, and $\mathrm{O}_{2}$ not included in alphabetical order (since they were a part of most reactions) but added to the end of the reaction. Therefore, all of the reactions were in a common format and it was simple to identify replicates by inspection. This also allowed for the discreet reactions to be uniquely identified by the first reactant (and a number where needed) in the reaction.

Many cycles are the subject of previous review articles. Data for these cycles was entered directly into the cycle database and, as the literature search identified additional cycles, they were added to the cycle database. Basic bibliographic data for each additional literature source, referring to a particular cycle, was added to the cycle database and linked to the cycle. 


\section{LITERATURE SEARCH}

The literature survey was designed to locate substantially all thermochemical watersplitting cycles that have been proposed in the open literature. Keywords were chosen and test searches were made using free or inexpensive databases as a means of testing search strategies. Thermochemical generation of hydrogen is usually referred to, by those who practice the art, as water-splitting. It was quickly determined that searches based upon water-splitting and "water splitting" lead to many thousands of hits - few of which were pertinent to the desired subject. Inspection of the titles showed a predominance of biological, biochemical and photochemical articles and numerous titles dealing with corrosion and radiolysis, moreover, some authors do not use the term water-splitting. Attempts to limit the search, by exclusion of biological and photochemical terms (Boolean NOT) exceeded the capabilities of the search engines before a significant reduction in number of hits was realized. It has proven to be much more profitable to build up a search criteria using inclusive criteria (Boolean AND/OR). The primary limit on the search has been the requirement of the inclusion of the term "thermochemical".

Chemical Abstracts Service (of the American Chemical Society) provides convenient access to many databases. Searching a large number of different databases can be very expensive and may produce a large number of redundant references to a single publication. The web site stnweb.cas.org allows one to simultaneously search a large number of databases at no cost, but the only results provided are the number of hits. This free search does allow one to quickly and inexpensively test various search strategies. Various Boolean searches were made of the CHEMENG cluster of databases in an attempt to optimize the search string and select the databases to be used for the "real" search. The search term [(water-splitting or watersplitting or ((hydrogen or h2) and (production or generation))) and thermochemical] appeared to give very good results. The results from the databases showing a significant number of hits are given in Table 1.

The CAPLUS database was subjected to a full data retrieval search: over $50 \%$ of the hits are for papers related to thermochemical water-splitting. From the descriptors given for the various databases, it is likely that full searches of these databases, with the exception of NTIS, will result in hits that either duplicate hits resulting from the CAPLUS search or references previously entered into the EndNote literature database. 
TABLE 1

\section{DATABASE HIT RESULTS}

\begin{tabular}{|c|c|c|}
\hline Hits & Databases & Description \\
\hline 905 & CAPLUS & Chemical Abstracts Plus \\
\hline 448 & COMPENDEX & COMPuterized ENgineering InDEX \\
\hline 440 & NTIS & National Technical Information Service \\
\hline 322 & INSPEC & $\begin{array}{l}\text { The Database for Physics, Electronics and Computing. } \\
\text { INSPEC corresponds to Physics Abstracts, Electrical \& } \\
\text { Electronics Abstracts, Computer \& Control Abstracts, and } \\
\text { Business Automation. }\end{array}$ \\
\hline 232 & SCISEARCH & Science Citation Index Expanded \\
\hline 68 & CEABA & Chemical Engineering And Biotechnology Abstracts \\
\hline 33 & PROMT & $\begin{array}{l}\text { Predicasts Overview of Markets and Technology - abstracts } \\
\text { trade and business journals }\end{array}$ \\
\hline 28 & INSPHYS & $\begin{array}{l}\text { INSPHYS is a supplementary file to the INSPEC database. It } \\
\text { contains those records from the former PHYS File from } 1979 \\
\text { through } 1994 \text { that do not appear in INSPEC }\end{array}$ \\
\hline
\end{tabular}

The NTIS database, the DOE PubSCIENCE database (www.osti.gov/pubsci) and the IBM Patent Server (www.ibm.com/patent) were searched and the results added to the literature database.

The EndNote database contains 792 entries, after purging duplicate and irrelevant entries. Figure 2 indicates when the references were published. The last review of the subject was published in 1988, just as the major funding in this area decreased worldwide. Since that time about eight papers per year have been published which are related to thermochemical water-splitting. 


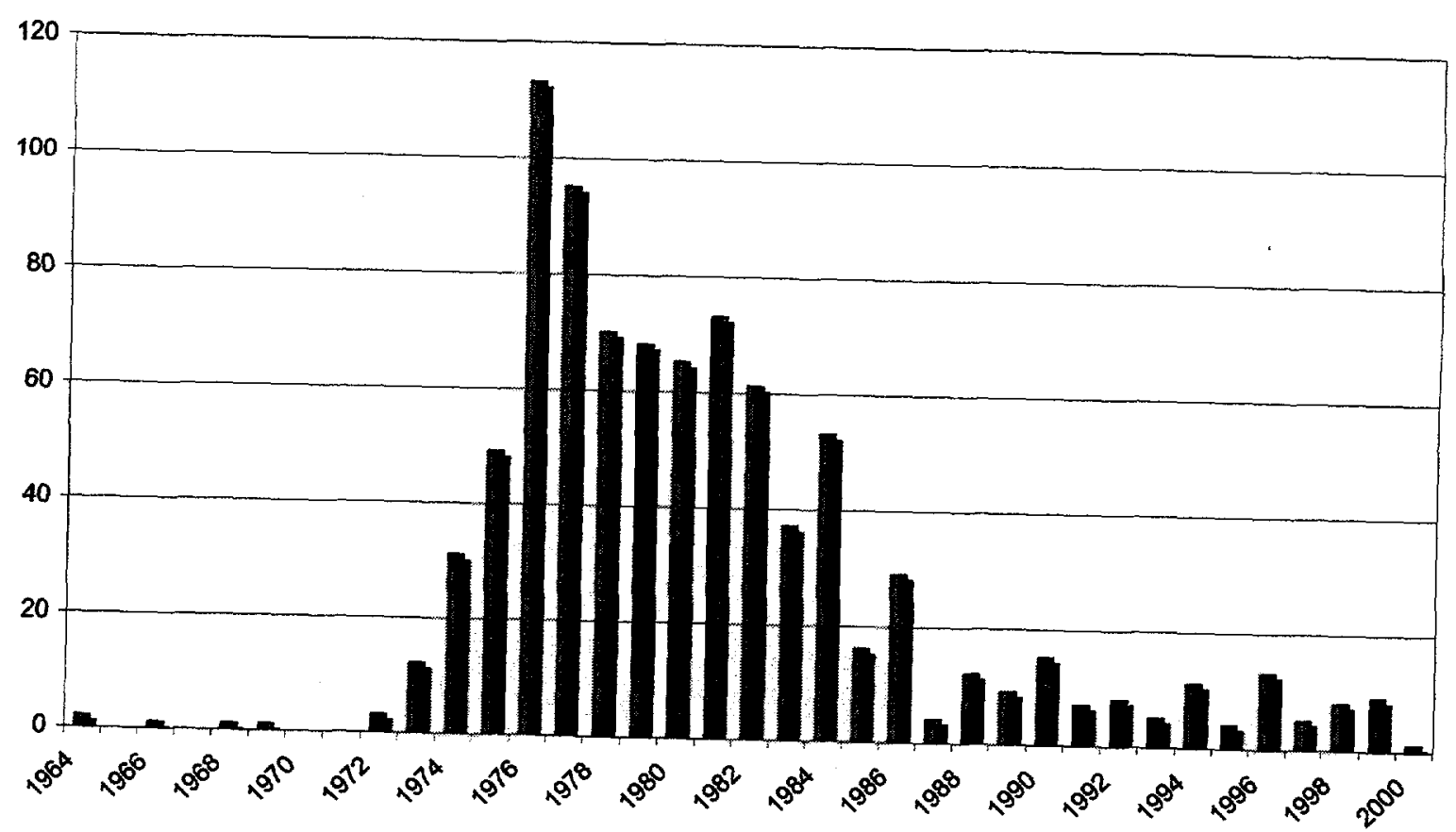

Fig. 2. Publications by year of issue. 


\section{SELECTION CRITERIA}

As expected, the literature search turned up a large number of cycles (115), far too many to analyze in depth. In order to establish objective screening criteria, with which to reduce the number of cycles to a manageable number, it was necessary to establish meaningful and quantifiable criteria. The criteria given in Table 2 were presented in the original proposal. Our first task was to determine if, indeed, these were the appropriate criteria and if so, to establish metrics by which each proposed cycle could be evaluated according to each criterion. We also needed to establish weighing factors for each criterion with which to establish a final weighted score for each cycle.

The criteria ultimately agreed upon are very similar to those originally proposed. Table 3 gives the basis for selecting the screening criteria and the metrics finally chosen. The translation of each metric, to a score based on the metric, is given in Table 4. Where possible the metrics are calculated from data, otherwise they are a consensus judgment of the principal investigators. Equal weighting was given to each criterion in calculating the final score for each process.

One of the original criteria was left out of the methodology because a simple metric could not be devised that would permit a score to be calculated from first principles. We decided that Environmental, Safety and Health (ES\&H) concerns would be taken into account on a case by case basis after the list of cycles was limited using the numerical screening process. 
TABLE 2

PROPOSED INITIAL SCREENING CRITERIA

\begin{tabular}{|c|c|}
\hline Criteria & Impact \\
\hline $\begin{array}{l}\text { 1. Number of reactions and/or separation } \\
\text { steps in the cycle }\end{array}$ & $\begin{array}{l}\text { Smaller number indicated reduces process } \\
\text { complexity and cost }\end{array}$ \\
\hline 2. Number of elements in the cycle & $\begin{array}{l}\text { Smaller number indicates less } \\
\text { cost/complexity in element recovery }\end{array}$ \\
\hline $\begin{array}{l}\text { 3. Cost and availability of process } \\
\text { chemicals }\end{array}$ & There may be strategic availability issues \\
\hline $\begin{array}{l}\text { 4. Corrosiveness of the process media and } \\
\text { availability/cost of materials of } \\
\text { construction and cost must be considered }\end{array}$ & $\begin{array}{l}\text { Improved materials of construction may } \\
\text { allow consideration of processes } \\
\text { previously dismissed yet effect on } \\
\text { hydrogen production efficiency }\end{array}$ \\
\hline $\begin{array}{l}\text { 5. Are non-stationary solid reactants } \\
\text { involved? }\end{array}$ & $\begin{array}{l}\text { Bulk movement of solid reactants greatly } \\
\text { increases processing difficulty and cost }\end{array}$ \\
\hline $\begin{array}{l}\text { 6. Projected effect of higher temperatures } \\
\text { on cost }\end{array}$ & $\begin{array}{l}\text { This addresses the potential for higher } \\
\text { hydrogen production cycle efficiency and } \\
\text { temperatures in future nuclear reactors }\end{array}$ \\
\hline $\begin{array}{l}\text { 7. Environmental, Safety and Health (ESH) } \\
\text { considerations }\end{array}$ & $\begin{array}{l}\text { Are there basic environmental safety and } \\
\text { health issues with the cycle? }\end{array}$ \\
\hline 8. Amount of research done & $\begin{array}{l}\text { Has the scientific basis of this cycle been } \\
\text { verified or is it a new process? }\end{array}$ \\
\hline $\begin{array}{l}\text { 9. Was at least a bench scale continuous } \\
\text { flow model operated }\end{array}$ & Indicates the relative maturity of a process \\
\hline $\begin{array}{l}\text { 10. Are efficiency and/or cost figures } \\
\text { available? How good are they? }\end{array}$ & $\begin{array}{l}\text { Indicates a significant amount of } \\
\text { engineering design work }\end{array}$ \\
\hline
\end{tabular}


TABLE 3

RATIONAL FOR DEVELOPMENT OF FIRST ROUND SCREENING CRITERIA

\begin{tabular}{|c|c|c|}
\hline Desirable Characteristic & Rational & Metric \\
\hline $\begin{array}{l}1 \text { Higher ranked cycles will have a minimum number } \\
\text { of chemical reactions steps in the cycle. }\end{array}$ & $\begin{array}{l}\text { A smaller number of chemical reactions indicates a simpler } \\
\text { process and lower costs. }\end{array}$ & $\begin{array}{l}\text { Score is based on number of chemical } \\
\text { reactions. }\end{array}$ \\
\hline $\begin{array}{l}2 \text { Higher ranked cycles will have a minimum number } \\
\text { of separation steps in the cycle. }\end{array}$ & $\begin{array}{l}\text { A smaller number of chemical separations indicates a simpler } \\
\text { process and lower costs. }\end{array}$ & $\begin{array}{l}\text { Score is based on number of chemical } \\
\text { separations, excluding simple phase } \\
\text { separation. }\end{array}$ \\
\hline $\begin{array}{l}3 \text { Higher ranked cycles will have a minimum number } \\
\text { of elements in the cycle. }\end{array}$ & $\begin{array}{l}\text { A smaller number of chemical elements indicates a simpler } \\
\text { process and lower costs. }\end{array}$ & $\begin{array}{l}\text { Score is based on number of elements, } \\
\text { excluding oxygen and hydrogen }\end{array}$ \\
\hline $\begin{array}{l}4 \text { Higher ranked cycles will employ elements which } \\
\text { are abundant in the earth's crust, oceans and } \\
\text { atmosphere. }\end{array}$ & $\begin{array}{l}\text { Use of abundant elements will lower the cost and permit the } \\
\text { chosen technology to be implemented on a large scale. There } \\
\text { may be strategic availability issues. }\end{array}$ & $\begin{array}{l}\text { Score is based on least abundant element in } \\
\text { cycle. }\end{array}$ \\
\hline $\begin{array}{l}5 \text { Higher ranked cycles will minimize the use of } \\
\text { expensive materials of construction by avoiding } \\
\text { corrosive chemical systems, particularly in heat } \\
\text { exchangers. }\end{array}$ & $\begin{array}{l}\text { Improved materials of construction may allow consideration of } \\
\text { processes previously dismissed yet the effect of materials cost on } \\
\text { hydrogen production efficiency and cost must be considered. }\end{array}$ & $\begin{array}{l}\text { Score is based on the relative corrosiveness } \\
\text { of the process solutions. }\end{array}$ \\
\hline $\begin{array}{l}6 \text { Higher ranked cycles will minimize the flow of } \\
\text { solids. }\end{array}$ & $\begin{array}{l}\text { Chemical plant costs are considerably higher for solids processing } \\
\text { plants. Flow of solid materials also corresponds to increased } \\
\text { maintenance costs due to wear and to increased downtime due to } \\
\text { blockage and unscheduled equipment failure. }\end{array}$ & $\begin{array}{l}\text { Score is based on minimization of solid flow } \\
\text { problems. }\end{array}$ \\
\hline $\begin{array}{l}7 \text { Higher ranked cycles will have maximum heat } \\
\text { input temperature compatible with high } \\
\text { temperature heat transfer materials. }\end{array}$ & $\begin{array}{l}\text { High thermal efficiency cannot be realized without a high } \\
\text { temperature heat input to the water-splitting process. The limit on } \\
\text { temperature will be the thermal and mechanical performance of the } \\
\text { heat transfer material separating the reactor coolant from the } \\
\text { process stream requiring the highest temperature. }\end{array}$ & $\begin{array}{l}\text { Score is based on the high temperature heat } \\
\text { input to the process being close to that } \\
\text { delivered by an advanced nuclear reactor. }\end{array}$ \\
\hline $\begin{array}{l}8 \text { Higher ranked cycles will have been the subject of } \\
\text { many papers from many authors and institutions. }\end{array}$ & $\begin{array}{l}\text { Cycles that have been thoroughly studied in the literature have a } \\
\text { lower probability of having undiagnosed flaws. }\end{array}$ & $\begin{array}{l}\text { Score will be based on the number of papers } \\
\text { published dealing with the cycle. }\end{array}$ \\
\hline $\begin{array}{l}9 \text { Higher ranked cycles will have been tested at a } \\
\text { moderate or large scale, }\end{array}$ & $\begin{array}{l}\text { Relatively mature processes will have had their unit operations } \\
\text { tested at relatively large scale. Processes for which the basic } \\
\text { chemistry has not been verified are suspect. }\end{array}$ & $\begin{array}{l}\text { Score will be based on the degree to which } \\
\text { the chemistry of the cycle has been actually } \\
\text { demonstrated and not just postulated. }\end{array}$ \\
\hline $\begin{array}{l}10 \text { Higher ranked cycles will have good efficiency } \\
\text { and cost data available. }\end{array}$ & $\begin{array}{l}\text { A significant amount of engineering design work is necessary to } \\
\text { estimate process efficiencies and production costs. Note: cost } \\
\text { estimates in the absence of efficiency calculations are meaningless } \\
\text { and will not be considered. }\end{array}$ & $\begin{array}{l}\text { Score will be based on the degree to which } \\
\text { efficiencies and cost have been estimated. }\end{array}$ \\
\hline
\end{tabular}




\section{TABLE 4}

METRICS USED TO SCORE PROCESSES. FOR EACH METRIC, THE PROCESS RECEIVES THE SCORE INDICATED. THE PROCESS SCORE IS THE SUM OF THE INDIVIDUAL SCORES

\begin{tabular}{|c|c|c|c|c|c|c|c|c|c|c|c|}
\hline Score $\Rightarrow$ & 0 & 1 & 2 & 3 & 4 & 5 & 6 & 7 & 8 & 9 & 10 \\
\hline $\begin{array}{l}\text { 1. Number of chemical } \\
\text { reactions }\end{array}$ & 6 & - & - & 5 & - & - & 4 & - & - & 3 & 2 \\
\hline $\begin{array}{l}\text { 2. Number of chemical } \\
\text { separation steps }\end{array}$ & 10 & 9 & 8 & 7 & 6 & 5 & 4 & 3 & 2 & 1 & 0 \\
\hline 3. Number of elements -2 & 7 & & 6 & - & 5 & - & 4 & - & 3 & 2 & 1 \\
\hline $\begin{array}{l}\text { 4. Least abundant element } \\
\text { in process }\end{array}$ & Ir & $\begin{array}{l}\text { Rh, Te, Os, } \\
\text { Ru, Re, Au }\end{array}$ & $\begin{array}{l}\mathrm{Pt}, \mathrm{Bi}, \mathrm{Pd} \\
\mathrm{Hg}, \mathrm{Se}\end{array}$ & $\begin{array}{l}\mathrm{Ag}, \mathrm{In}, \mathrm{Cd} \\
\mathrm{Sb}, \mathrm{Tm}, \mathrm{Tl}, \\
\mathrm{Lu}\end{array}$ & \begin{tabular}{|} 
I, Tb, W, Ho, \\
U, Ta, Mo, \\
Eu, Cs, Yb, \\
Er, Hf, Sn, Ge
\end{tabular} & $\begin{array}{l}\text { Th, As, Gd, } \\
\text { Dy, Sm, Pb, } \\
\text { Pr }\end{array}$ & $\begin{array}{r}\mathrm{Nb}, \mathrm{Be}, \mathrm{Nd} \\
\mathrm{La}, \mathrm{Ga}, \mathrm{Y}, \mathrm{Ce} \\
\mathrm{Co}, \mathrm{Sc}, \mathrm{Rb}\end{array}$ & $\begin{array}{l}\mathrm{Cu}, \mathrm{Zn}, \mathrm{Zr} \\
\mathrm{Ni}, \mathrm{B}, \mathrm{Ba} \\
\mathrm{Li}, \mathrm{Br}, \mathrm{Cr} \\
\mathrm{V}, \mathrm{Sr}\end{array}$ & $\mathrm{Mn}, \mathrm{F}, \mathrm{P}$ & $\begin{array}{l}\mathrm{S}, \mathrm{Ti}, \mathrm{C} \\
\mathrm{K}, \mathrm{N}\end{array}$ & $\begin{array}{l}\mathrm{Ca}, \mathrm{Mg}, \mathrm{Cl}, \\
\mathrm{Na}, \mathrm{Al}, \mathrm{Fe}, \mathrm{S}\end{array}$ \\
\hline $\begin{array}{l}\text { 5. Relative corrosiveness } \\
\text { of process solutions }\end{array}$ & \multicolumn{2}{|c|}{$\begin{array}{l}\text { Very corrosive, e.g. } \\
\text { aqua regia }\end{array}$} & & & \multicolumn{3}{|c|}{$\begin{array}{l}\text { Moderately corrosive, } \\
\text { e.g. sulfuric acid }\end{array}$} & & & & Not corrosive \\
\hline $\begin{array}{l}\text { 6. Degree to which process } \\
\text { is continuous and flow } \\
\text { of solids is minimized }\end{array}$ & $\begin{array}{l}\text { Batch flow } \\
\text { of solids }\end{array}$ & & & $\begin{array}{l}\text { Continuous } \\
\text { flow of solids }\end{array}$ & & \multicolumn{3}{|c|}{$\begin{array}{l}\text { Flow of gases or liquids through } \\
\text { packed beds }\end{array}$} & & \multicolumn{2}{|c|}{$\begin{array}{l}\text { Continuous flow of liquids } \\
\text { and gases }\end{array}$} \\
\hline $\begin{array}{l}\text { 7. Maximum temperature } \\
\text { in process }\left({ }^{\circ} \mathrm{C}\right)\end{array}$ & $\begin{array}{c}<300 \\
\text { or } \\
<1300\end{array}$ & $\begin{array}{c}300-350 \\
\text { or } \\
1250-1300\end{array}$ & $\begin{array}{c}350-400 \\
\text { or } \\
1200-1250\end{array}$ & $\begin{array}{c}400-450 \\
\text { or } \\
1150-1200\end{array}$ & $\begin{array}{l}450-500 \\
\text { or } \\
1100-1150\end{array}$ & $\begin{array}{c}500-550 \\
\text { or } \\
1050-1100\end{array}$ & $\begin{array}{c}550-600 \\
\text { or } \\
1000-1050\end{array}$ & $\begin{array}{c}600-650 \\
\text { or } \\
950-1000\end{array}$ & $\begin{array}{l}650-700 \\
\text { or } \\
900-950\end{array}$ & $\begin{array}{l}700-750 \\
\text { or } \\
850-900\end{array}$ & $750-850$ \\
\hline $\begin{array}{l}\text { 8. Number of published } \\
\text { references to cycle }\end{array}$ & 1 paper & \multicolumn{3}{|c|}{ A few papers } & \multicolumn{4}{|c|}{ Many papers } & \multicolumn{3}{|c|}{ Extensive literature base } \\
\hline $\begin{array}{l}\text { 9. Degree to which } \\
\text { chemistry of cycle has } \\
\text { been demonstrated }^{\dagger}\end{array}$ & $\begin{array}{c}\text { No laboratory } \\
\text { work }\end{array}$ & & & $\begin{array}{l}\text { Test tube } \\
\text { scale testing }\end{array}$ & & & $\begin{array}{l}\text { Bench scale } \\
\text { testing }\end{array}$ & & & & $\begin{array}{l}\text { Pilot plant } \\
\text { scale testing }\end{array}$ \\
\hline $\begin{array}{l}\text { 10. Degree to which good } \\
\text { efficiency and cost } \\
\text { data are available }\end{array}$ & \multicolumn{2}{|c|}{$\begin{array}{l}\text { No efficiency estimate } \\
\text { available }\end{array}$} & \multicolumn{2}{|c|}{$\begin{array}{c}\text { Thermodynamic efficiency } \\
\text { estimated from elementary } \\
\text { reactions. }\end{array}$} & \multicolumn{2}{|c|}{$\begin{array}{c}\text { Thermodynamic efficiency } \\
\text { estimate based on rough } \\
\text { flowsheet }\end{array}$} & \multicolumn{2}{|c|}{$\begin{array}{l}\text { Thermodynamic efficiency } \\
\text { calculation based on } \\
\text { detailed flow sheet }\end{array}$} & \multicolumn{3}{|c|}{$\begin{array}{l}\text { Detailed cost calculations, based on } \\
\text { detailed flowsheets available from one } \\
\text { or more independent sources. }\end{array}$} \\
\hline
\end{tabular}

\footnotetext{
${ }^{\dagger}$ Interpolate scores between defined scale points.
} 


\section{SELECTION PROCESS}

The selection process consisted of applying the metrics to each process and summing the scores to get an overall score for each process. Some of the metrics can be easily calculated but for the others, value judgments are required. The three principal investigators jointly went over these aspects of all 115 cycles to generate a consensus score for each cycle and for each metrics requiring a judgment call. The scores for Metrics 1,2, 3, 4 and 7 are readily evaluated with little subjective judgment required. The other metrics required a consensus judgment.

Metric 1 -Number of chemical reactions. Counting the number of chemical reactions is usually easy. An exception is when two or more chemical reactions occur sequentially in a single processing operation. In this case, we considered there to be just one reaction, for the purpose of calculating the score. This question arises primarily for cycles involving the decomposition of sulfuric acid. Most authors considered the reaction to be

$$
\mathrm{H}_{2} \mathrm{SO}_{4}(\mathrm{~g})\left(\mathrm{H}_{2} \mathrm{O}(\mathrm{g})+\mathrm{SO}_{2}(\mathrm{~g})+1 / 2 \mathrm{O}_{2}(\mathrm{~g})\right.
$$

whereas others, attempting to be more precise, considered there to be two reactions

$$
\mathrm{H}_{2} \mathrm{SO}_{4}(\mathrm{~g})\left(\mathrm{H}_{2} \mathrm{O}(\mathrm{g})+\mathrm{SO}_{3}(\mathrm{~g})\right.
$$

followed by

$$
\mathrm{SO}_{3}(\mathrm{~g})\left(\mathrm{SO}_{2}(\mathrm{~g})+1 / 2 \mathrm{O}_{2}(\mathrm{~g}) .\right.
$$

Since both reactions occur sequentially in a single heat exchanger/reactor system, without any intermediate separations, we considered there to be one reaction, independent of the way the cycle was described in the literature.

Metric 2 - Number of chemical separation steps. The number of separations for a cycle was determined from the number of separations required for each chemical reaction. Each chemical reaction is assumed to yield a mixture of its reactants and products. After phase separation, for each phase, there is one less separation than there are components, if the components must be separated before the next reaction. As an example, consider the reactions of the UT-3 cycle [3]. 


$$
\begin{aligned}
& \mathrm{Br}_{2}(\mathrm{~g})+\mathrm{CaO}(\mathrm{s})=\mathrm{CaBr}_{2}(\mathrm{~s})+1_{2} \mathrm{O}_{2}(\mathrm{~g}) \\
& 3 \mathrm{FeBr}_{2}(\mathrm{~s})+4 \mathrm{H}_{2} \mathrm{O}(\mathrm{g})=\mathrm{Fe}_{3} \mathrm{O}_{4}(\mathrm{~s})+6 \mathrm{HBr}(\mathrm{g})+\mathrm{H}_{2}(\mathrm{~g}) \\
& \mathrm{CaBr}_{2}(\mathrm{~s})+\mathrm{H}_{2} \mathrm{O}(\mathrm{g})=\mathrm{CaO}(\mathrm{s})+2 \mathrm{HBr}(\mathrm{g}) \\
& \mathrm{Fe}_{3} \mathrm{O}_{4}(\mathrm{~s})+8 \mathrm{HBr}(\mathrm{g})=\mathrm{Br}_{2}(\mathrm{~g})+3 \mathrm{FeBr}_{2}(\mathrm{~s})+4 \mathrm{H}_{2} \mathrm{O}(\mathrm{g})
\end{aligned}
$$

For this cycle, the solid reactants remain in fixed beds with the gas flow cycled between the beds as the temperatures are changed. The solids are never separated, even if the reaction is not driven to completion, so solid separations do not contribute to the score. Reaction 3 includes two gaseous species, bromine and oxygen, and therefore one separation. Reaction 4 has three gaseous species, water, hydrogen bromide and hydrogen, and thus two separations. Reactions 5 and 6 have two and three gaseous species and one and two separations giving a potential total of six separations for the process. We recognized that the hydrogen bromide/water mixtures from Reactions 4 and 5 could be fed to Reaction 6 without separation leaving three separations for a score of seven for this metric. Similar analyses were made for each cycle.

Metric 3-Number of elements. Every element found in any reaction of the cycle was listed and counted. Oxygen and hydrogen, which occur in every cycle, were ignored. Catalysts, which do not show in the reactions were also ignored.

Metric 4 - Elemental abundance. Elements were ordered based on their atomic abundance in the earth's crust and separated into groups differing by roughly an order of magnitude in abundance. An exception is nitrogen, which was grouped with more abundant elements based on its abundance in the atmosphere. The score was then based on the least abundant element employed in the cycle.

Metric 5-Corrosive chemicals. Cycles were rated based on the most corrosive materials in the process. If no corrosive materials are involved the cycles were given a 10. No cycle was rated worse than 5 , which was defined as equivalent to sulfuric acid

Metric 6 -Solids flow. Cycles were separated into four groups: (1) cycles involving only gases and liquids, (2) cycles in which solids remained in stationary beds, (3) cycles in which solids flow continuously and (4) cycles in which solids remain in stationary beds part of the time and are moved at other times. We assumed that solids could be processed in static beds if only gas solid reactions were involved and all solid reactants resulted in solid products. We assumed that batch flow of solids would be necessary if 
liquids were converted to solids. It might not be strictly necessary that there be batch flow of solids in this case but the complications would be equally onerous and the score would be the same.

Metric 7 - Maximum cycle temperature. The maximum cycle temperature was another parameter requiring analysis. The score was reduced if the maximum temperature was either above or below that deemed optimum for an advanced high-temperature nuclear reactor. We used the temperatures given by the cycle proponents except where that would lower the score or when the value suggested produced a large positive for a non-electrolytic reaction. As an example of the former, Reaction 1 is part of several different cycles. The temperature of this reaction is quoted anywhere between $700^{\circ} \mathrm{C}$ and $1100^{\circ} \mathrm{C}$. This reaction actually represents the sequence of Reactions 2 (a) and 2(b). The Gibbs free energy of Reaction 2(b) changes relatively little over the range from $700^{\circ} \mathrm{C}$ to $1100^{\circ} \mathrm{C}$ so the net result of changing the temperature is to shift the equilibrium towards the products. It is not reasonable to give different cycles different scores based on use of the same high-temperature chemical reaction. In cases like this, we gave the maximum reasonable score to all cycles. In cases where the cycle proponents gave a temperature for which the reaction was non-spontaneous, i.e., it has a very positive Gibbs free energy, we assigned the temperature where the free energy was near zero. We used HSC [2] to calculate the free energy of each reaction as a function of temperature.

Metric 8 - References. The number of publications was determined from the literature search. Most cycles had either very few publications or very many publications

Metric 9-Chemical demonstration. The degree and scale to which the chemistry has been demonstrated was determined from the literature.

Metric 10 - Efficiency and cost data. The degree to which costs and efficiencies have been calculated was determined from the literature.

There was a significant correlation between the scores from the last three metrics. Leaving these metrics out of the scoring had little effect on which cycles scored best. This is probably because previous work has concentrated on cycles with few reactions, simple separations, available materials, which have minimal solids flow problems and which have their heat input requirements at reasonable temperatures. 


\section{SHORT LIST}

The screening criteria were applied to all 115 cycles and the results were sorted according to the total number of screening points awarded to each process. We had hoped that the totals would cluster in to high scoring and low scoring cycles to make the down selection easy, but this was not the case. We therefore somewhat arbitrarily used 50 points as the cut-off score. The original goal was to retain 20-30 cycles, after down selection, for more detailed evaluation. Using 50 points as the cut-off gave over 40 cycles, which allowed us room to apply ES\&H considerations as well as well as other "sanity checks".

Three additional go/no-go tests were applied to the short list. Two cycles were eliminated for ES\&H reasons in that they are based on mercury and we do not believe that it would be possible to license such a plant. Three cycles were eliminated because they require temperatures in excess of $1600^{\circ} \mathrm{C}$, which places them outside the scope of processes which are compatible with advanced nuclear reactors contemplated in the next 50 years. Additionally, HSC allowed us to analyze cycles for thermodynamic feasibility earlier in the screening process than we had originally foreseen. Seven cycles were eliminated because they had reactions that have large positive free energies that cannot be accomplished electrochemically. The final short list of 25 cycles is given in Table 5, along with their scores. One literature reference is included for each cycle. Details for these cycles are given in Table 6. 
TABLE 5

SHORT LIST OF CYCLOES AND THEIR SCORES

\begin{tabular}{|c|c|c|c|c|c|c|c|c|c|c|c|c|c|c|c|c|c|c|}
\hline $\begin{array}{l}\stackrel{?}{0} \\
\frac{9}{9} \\
\#\end{array}$ & ż & $\frac{\Omega}{90}$ & $\begin{array}{l}z=3 \\
\bar{x} \\
\vec{y} \\
\frac{\mathbf{D}}{3}\end{array}$ & $\begin{array}{l}\frac{m}{9} \\
\frac{9}{9} \\
\frac{\Phi}{\sigma}\end{array}$ & 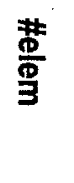 & $\begin{array}{l}\text { 莟 } \\
\text { 总 }\end{array}$ & $\begin{array}{l}\text { 替 } \\
\text { 总 }\end{array}$ & $\begin{array}{l}\overrightarrow{x_{x}} \\
\text { 出 }\end{array}$ & $\begin{array}{l}\text { N } \\
\text { 趸 }\end{array}$ & $\begin{array}{l}\omega \\
\text { m } \\
\stackrel{m}{g}\end{array}$ & $\begin{array}{l}\vec{z} \\
\frac{\vec{z}}{2}\end{array}$ & $\begin{array}{l}\text { cr } \\
\stackrel{8}{\rightrightarrows}\end{array}$ & $\begin{array}{l}\infty \\
\check{0} \\
\frac{0}{n}\end{array}$ & $\begin{array}{l}\overrightarrow{1} \\
\overrightarrow{9} \\
\overrightarrow{3}\end{array}$ & 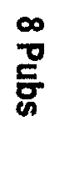 & 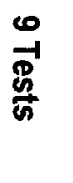 & 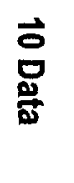 & 总 \\
\hline 1 & Westinghouse [4] & $H$ & $850 \mathrm{~S}$ & & 1 & 2 & 2 & 10 & 8 & 10 & 9 & 5 & 10 & 9 & 10 & 6 & 8 & 85 \\
\hline 2 & Ispra Mark 13 [5] & $\mathrm{H}$ & $850 \mathrm{Br}, \mathrm{S}$ & & 2 & 3 & 3 & 9 & 7 & 9 & 7 & 5 & 10 & 9 & 10 & 6 & 8 & 80 \\
\hline 3 & UT-3 Univ. of Tokyo [3] & $T$ & $750 \mathrm{Br}, \mathrm{Ca}, \mathrm{Fe}$ & & 3 & 3 & 4 & 6 & 7 & 8 & 7 & 5 & 6 & 10 & 10 & 10 & 10 & 79 \\
\hline 4 & GA Sulfur-lodine [6] & $T$ & 8001,5 & & 2 & 3 & 3 & 9 & 7 & 9 & 4 & 5 & 10 & 10 & 10 & 6 & 8 & 78 \\
\hline 5 & Julich Center EOS [7] & $T$ & $800 \mathrm{Fe}, \mathrm{S}$ & & 2 & 3 & 3 & 9 & 7 & 9 & 9 & 9 & 6 & 10 & 3 & 3 & 3 & 68 \\
\hline 6 & Tokyo Inst. Tech. Ferrite [8] & $T$ & $1000 \mathrm{Fe}, \mathrm{Mn}, \mathrm{Na}$ & & 3 & 2 & 2 & 10 & 8 & 8 & 8 & 10 & 10 & 6 & 2 & 2 & 0 & 64 \\
\hline 7 & Hallett Air Products 1965 [7] & $H$ & $800 \mathrm{Cl}$ & & 1 & 3 & 2 & 10 & 7 & 10 & 10 & 5 & 10 & 10 & 0 & 0 & 0 & 62 \\
\hline 8 & Gaz de France [7] & $\mathrm{T}$ & $825 \mathrm{~K}$ & & 1 & 3 & 3 & 9 & 7 & 10 & 9 & 5 & 6 & 10 & 2 & 2 & 2 & 62 \\
\hline 9 & Nickel Ferrite [9] & $T$ & $1000 \mathrm{Fe}, \mathrm{Ni}, \mathrm{Mn}$ & & 3 & 0 & 2 & 10 & 10 & 8 & 7 & 10 & 6 & 6 & 0 & 3 & 0 & 60 \\
\hline 10 & Aachen Univ Julich 1972 [7] & $\mathrm{T}$ & $800 \mathrm{Cr}, \mathrm{Cl}$ & & 2 & 3 & 3 & 9 & 7 & 9 & 7 & 5 & 6 & 10 & 2 & 2 & 2 & 59 \\
\hline 11 & Ispra Mark 1C [5] & $\mathrm{T}$ & $900 \mathrm{Br}, \mathrm{Ca}, \mathrm{Cu}$ & & 3 & 4 & 4 & 6 & 6 & 8 & 7 & 5 & 10 & 8 & 2 & 3 & 3 & 58 \\
\hline 12 & LASL- U [7] & $T$ & $700 \mathrm{C}, \mathrm{U}$ & & 2 & 3 & 3 & 9 & 7 & 9 & 4 & 10 & 6 & 9 & 1 & 3 & 0 & 58 \\
\hline 13 & Ispra Mark 8 [5] & $T$ & $900 \mathrm{Cl}, \mathrm{Mn}$ & & 2 & 3 & 3 & 9 & 7 & 9 & 8 & 5 & 3 & 8 & 3 & 2 & 3 & 57 \\
\hline 14 & Ispra Mark 6 [5] & $T$ & $800 \mathrm{Cl}, \mathrm{Cr}, \mathrm{Fe}$ & & 3 & 4 & 4 & 6 & 6 & 8 & 7 & 5 & 6 & 10 & 2 & 3 & 3 & 56 \\
\hline 15 & Ispra Mark 4 [5] & $\mathrm{T}$ & $800 \mathrm{Cl}, \mathrm{Fe}$ & & 2 & 4 & 4 & 6 & 6 & 9 & 10 & 5 & 0 & 10 & 3 & 3 & 3 & 55 \\
\hline 16 & Ispra Mark 3 [5] & $T$ & $800 \mathrm{Cl}, \mathrm{V}$ & & 2 & 3 & 3 & 9 & 7 & 9 & 7 & 5 & 0 & 10 & 2 & 3 & 3 & 55 \\
\hline 17 & Ispra Mark 2 (1972) [5] & $T$ & $800 \mathrm{C}, \mathrm{Na}, \mathrm{Mn}$ & & 3 & 3 & 3 & 9 & 7 & 8 & 8 & 5 & 0 & 10 & 2 & 3 & 3 & 55 \\
\hline 18 & $\mathrm{CO} / \mathrm{Mn} 304[10]$ & $T$ & $977 \mathrm{C}, \mathrm{Mn}$ & & 2 & 3 & 3 & 9 & 7 & 9 & 8 & 9 & 6 & 7 & 0 & 0 & 0 & 55 \\
\hline 19 & Ispra Mark 7B [5] & $T$ & $1000 \mathrm{Cl}, \mathrm{Fe}$ & & 2 & 5 & 5 & 3 & 5 & 9 & 10 & 5 & 10 & 6 & 0 & 3 & 3 & 54 \\
\hline 20 & Vanadium Chloride [11] & $\mathrm{T}$ & $700 \mathrm{Cl}, \mathrm{V}$ & & 3 & 5 & 4 & 6 & 5 & 8 & 7 & 5 & 6 & 9 & 3 & 2 & 2 & 53 \\
\hline 21 & Ispra Mark 7A [5] & $\mathrm{T}$ & $1000 \mathrm{Cl}, \mathrm{Fe}$ & & 2 & 5 & 5 & 3 & 5 & 9 & 10 & 5 & 6 & 6 & 3 & 3 & 3 & 53 \\
\hline 22 & GA Cycle 23 [12] & $\mathrm{T}$ & $850 \mathrm{~S}$ & & 2 & 4 & 5 & 3 & 6 & 9 & 9 & 5 & 10 & 9 & 0 & 0 & 0 & 51 \\
\hline 23 & US -Chlorine [7] & $T$ & $993 \mathrm{Cl}, \mathrm{Cu}$ & & 2 & 3 & 3 & 9 & 7 & 9 & 7 & 6 & 5 & 7 & 0 & 0 & 0 & 50 \\
\hline 24 & Ispra Mark 9 [5] & $\mathrm{T}$ & $450 \mathrm{Cl}, \mathrm{Fe}$ & & 2 & 8 & 3 & 9 & 2 & 9 & 10 & 5 & 3 & 4 & 2 & 3 & 3 & 50 \\
\hline 25 & Ispra Mark 6C [5] & $T$ & $800 \mathrm{Cl}, \mathrm{Cr}, \mathrm{Cu}, \mathrm{Fe}$ & & 4 & 5 & 5 & 3 & 5 & 6 & 7 & 5 & 6 & 10 & 2 & 3 & 3 & 50 \\
\hline
\end{tabular}

${ }^{*} \mathrm{~T}=$ Thermochemical, $\mathrm{H}=$ Hybrid Thermochemical/Electorchemical 
TABLE 6

REACTION DETAILS FOR CYCLES

\begin{tabular}{|c|c|c|c|c|c|}
\hline Cycle & Name & $\mathrm{T} / \mathrm{E}^{*}$ & $\mathrm{~T}^{\circ} \mathrm{C}$ & Reaction & $F^{\dagger}$ \\
\hline 1 & Westinghouse [4] & $\begin{array}{l}\mathrm{T} \\
\mathrm{E}\end{array}$ & $\begin{array}{c}850 \\
77\end{array}$ & $\begin{array}{l}2 \mathrm{H}_{2} \mathrm{SO}_{4}(\mathrm{~g})=2 \mathrm{SO}_{2}(\mathrm{~g})+2 \mathrm{H}_{2} \mathrm{O}(\mathrm{g})+\mathrm{O}_{2}(\mathrm{~g}) \\
\mathrm{SO}_{2}(\mathrm{~g})+2 \mathrm{H}_{2} \mathrm{O}(\mathrm{a})=\mathrm{H}_{2} \mathrm{SO}_{4}(\mathrm{a})+\mathrm{H}_{2}(\mathrm{~g})\end{array}$ & $\begin{array}{c}1 / 2 \\
1\end{array}$ \\
\hline 2 & Ispra Mark 13 [5] & $\begin{array}{l}\mathrm{T} \\
\mathrm{E} \\
\mathrm{T}\end{array}$ & $\begin{array}{c}850 \\
77 \\
77\end{array}$ & $\begin{array}{l}2 \mathrm{H}_{2} \mathrm{SO}_{4}(\mathrm{~g})=2 \mathrm{SO}_{2}(\mathrm{~g})+2 \mathrm{H}_{2} \mathrm{O}(\mathrm{g})+\mathrm{O}_{2}(\mathrm{~g}) \\
2 \mathrm{HBr}(\mathrm{a})=\mathrm{Br}_{2}(\mathrm{a})+\mathrm{H}_{2}(\mathrm{~g}) \\
\mathrm{Br}_{2}(\mathrm{l})+\mathrm{SO}_{2}(\mathrm{~g})+2 \mathrm{H}_{2} \mathrm{O}(\mathrm{l})=2 \mathrm{HBr}(\mathrm{g})+\mathrm{H}_{3} \mathrm{SO}_{4}(\mathrm{a})\end{array}$ & $\begin{array}{l}1 / 2 \\
1 \\
1\end{array}$ \\
\hline 3 & UT-3 Univ. of Tokyo [3] & $\begin{array}{l}\mathrm{T} \\
\mathrm{T} \\
\mathrm{T} \\
\mathrm{T}\end{array}$ & $\begin{array}{l}600 \\
600 \\
750 \\
300\end{array}$ & $\begin{array}{l}2 \mathrm{Br}_{2}(\mathrm{~g})+2 \mathrm{CaO}=2 \mathrm{CaBr}_{2}+\mathrm{O}_{2}(\mathrm{~g}) \\
3 \mathrm{FeBr}_{2}+4 \mathrm{H}_{2} \mathrm{O}=\mathrm{Fe}_{3} \mathrm{O}_{4}+6 \mathrm{HBr}+\mathrm{H}_{2}(\mathrm{~g}) \\
\mathrm{CaBr}_{2}+\mathrm{H}_{2} \mathrm{O}=\mathrm{CaO}+2 \mathrm{HBr} \\
\mathrm{Fe}_{3} \mathrm{O}_{4}+8 \mathrm{HBr}=\mathrm{Br}_{2}+3 \mathrm{FeBr}_{2}+4 \mathrm{H}_{2} \mathrm{O}\end{array}$ & $\begin{array}{c}1 / 2 \\
1 \\
1 \\
1\end{array}$ \\
\hline 4 & GA Sulfur-Iodine [6] & $\begin{array}{l}\mathrm{T} \\
\mathrm{T} \\
\mathrm{T}\end{array}$ & $\begin{array}{l}850 \\
300 \\
100\end{array}$ & $\begin{array}{l}2 \mathrm{H}_{2} \mathrm{SO}_{4}(\mathrm{~g})=2 \mathrm{SO}_{2}(\mathrm{~g})+2 \mathrm{H}_{2} \mathrm{O}(\mathrm{g})+\mathrm{O}_{2}(\mathrm{~g}) \\
2 \mathrm{HI}=\mathrm{I}_{2}(\mathrm{~g})+\mathrm{H}_{2}(\mathrm{~g}) \\
\mathrm{I}_{2}+\mathrm{SO}_{2}(\mathrm{a})+2 \mathrm{H}_{2} \mathrm{O}=2 \mathrm{HI}(\mathrm{a})+\mathrm{H}_{2} \mathrm{SO}_{4}(\mathrm{a})\end{array}$ & $\begin{array}{l}1 / 2 \\
1 \\
1\end{array}$ \\
\hline 5 & Julich Center EOS [7] & $\begin{array}{l}\mathrm{T} \\
\mathrm{T} \\
\mathrm{T}\end{array}$ & $\begin{array}{l}800 \\
700 \\
200\end{array}$ & $\begin{array}{l}2 \mathrm{Fe}_{3} \mathrm{O}_{4}+6 \mathrm{FeSO}_{4}=6 \mathrm{Fe}_{2} \mathrm{O}_{3}+6 \mathrm{SO}_{2}+\mathrm{O}_{2}(\mathrm{~g}) \\
3 \mathrm{FeO}+\mathrm{H}_{2} \mathrm{O}=\mathrm{Fe}_{3} \mathrm{O}_{4}+\mathrm{H}_{2}(\mathrm{~g}) \\
\mathrm{Fe}_{2} \mathrm{O}_{3}+\mathrm{SO}_{2}=\mathrm{FeO}+\mathrm{FeSO}_{4}\end{array}$ & $\begin{array}{l}1 / 2 \\
1 \\
6\end{array}$ \\
\hline 6 & Tokyo Inst. Tech. Ferrite [8] & $\begin{array}{l}\mathrm{T} \\
\mathrm{T}\end{array}$ & $\begin{array}{l}1000 \\
600\end{array}$ & $\begin{array}{l}2 \mathrm{MnFe}_{2} \mathrm{O}_{4}+3 \mathrm{Na}_{2} \mathrm{CO}_{3}+\mathrm{H}_{2} \mathrm{O}=2 \mathrm{Na}_{3} \mathrm{MnFe}_{2} \mathrm{O}_{6}+ \\
3 \mathrm{CO}_{2}(\mathrm{~g})+\mathrm{H}_{2}(\mathrm{~g}) \\
4 \mathrm{Na}_{3} \mathrm{MnFe}_{2} \mathrm{O}_{6}+6 \mathrm{CO}_{2}(\mathrm{~g})=4 \mathrm{MnFe}_{2} \mathrm{O}_{4}+ \\
6 \mathrm{Na}_{2} \mathrm{CO}_{3}+\mathrm{O}_{2}(\mathrm{~g})\end{array}$ & $1 / 2$ \\
\hline 7 & Hallett Air Products 1965 [7] & $\begin{array}{l}\mathrm{T} \\
\mathrm{E}\end{array}$ & $\begin{array}{l}800 \\
25\end{array}$ & $\begin{array}{l}2 \mathrm{Cl}_{2}(\mathrm{~g})+2 \mathrm{H}_{2} \mathrm{O}(\mathrm{g})=4 \mathrm{HCl}(\mathrm{g})+\mathrm{O}_{2}(\mathrm{~g}) \\
2 \mathrm{HCl}=\mathrm{Cl}_{2}(\mathrm{~g})+\mathrm{H}_{2}(\mathrm{~g})\end{array}$ & $\begin{array}{c}1 / 2 \\
1\end{array}$ \\
\hline 8 & Gaz de France [7] & $\begin{array}{l}\mathrm{T} \\
\mathrm{T} \\
\mathrm{T}\end{array}$ & $\begin{array}{l}725 \\
825 \\
125\end{array}$ & $\begin{array}{l}2 \mathrm{~K}+2 \mathrm{KOH}=2 \mathrm{~K}_{2} \mathrm{O}+\mathrm{H}_{2}(\mathrm{~g}) \\
2 \mathrm{~K}_{2} \mathrm{O}=2 \mathrm{~K}+\mathrm{K}_{2} \mathrm{O}_{2} \\
2 \mathrm{~K}_{2} \mathrm{O}_{2}+2 \mathrm{H}_{2} \mathrm{O}=4 \mathrm{KOH}+\mathrm{O}_{2}(\mathrm{~g})\end{array}$ & $\begin{array}{l}1 \\
1 \\
1 / 2\end{array}$ \\
\hline 9 & Nickel Ferrite [9] & $\begin{array}{l}\mathrm{T} \\
\mathrm{T}\end{array}$ & $\begin{array}{l}800 \\
800\end{array}$ & $\begin{array}{l}\mathrm{NiMnFe}_{4} \mathrm{O}_{6}+2 \mathrm{H}_{2} \mathrm{O}=\mathrm{NiMnFe}_{4} \mathrm{O}_{8}+2 \mathrm{H}_{2}(\mathrm{~g}) \\
\mathrm{NiMnFe}_{4} \mathrm{O}_{8}=\mathrm{NiMnFe}_{4} \mathrm{O}_{6}+\mathrm{O}_{2}(\mathrm{~g})\end{array}$ & $\begin{array}{c}1 \\
1 / 2\end{array}$ \\
\hline 10 & Aachen Univ Julich 1972 [7] & $\begin{array}{l}T \\
T \\
T\end{array}$ & $\begin{array}{l}850 \\
170 \\
800\end{array}$ & $\begin{array}{l}2 \mathrm{Cl}_{2}(\mathrm{~g})+2 \mathrm{H}_{2} \mathrm{O}(\mathrm{g})=4 \mathrm{HCl}(\mathrm{g})+\mathrm{O}_{2}(\mathrm{~g}) \\
2 \mathrm{CrCl}_{2}+2 \mathrm{HCl}=2 \mathrm{CrCl}_{3}+\mathrm{H}_{2}(\mathrm{~g}) \\
2 \mathrm{CrCl}_{3}=2 \mathrm{CrCl}_{2}+\mathrm{Cl}_{2}(\mathrm{~g})\end{array}$ & $\begin{array}{r}1 / 2 \\
1 \\
1\end{array}$ \\
\hline \multirow[t]{2}{*}{11} & Ispra Mark 1C [5] & $\begin{array}{l}\mathrm{T} \\
\mathrm{T}\end{array}$ & $\begin{array}{l}100 \\
900\end{array}$ & $\begin{array}{l}2 \mathrm{CuBr}_{2}+\mathrm{Ca}(\mathrm{OH})_{2}=2 \mathrm{CuO}+2 \mathrm{CaBr}_{2}+\mathrm{H}_{2} \mathrm{O} \\
4 \mathrm{CuO}(\mathrm{s})=2 \mathrm{Cu}_{2} \mathrm{O}(\mathrm{s})+\mathrm{O}_{2}(\mathrm{~g})\end{array}$ & $\begin{array}{l}1 \\
1 / 2\end{array}$ \\
\hline & & T & $\begin{array}{l}730 \\
100\end{array}$ & $\begin{array}{l}\mathrm{CaBr}_{2}+2 \mathrm{H}_{2} \mathrm{O}=\mathrm{Ca}(\mathrm{OH})_{2}+2 \mathrm{HBr} \\
\mathrm{Cu}_{2} \mathrm{O}+4 \mathrm{HBr}=2 \mathrm{CuBr}_{2}+\mathrm{H}_{2}(\mathrm{~g})+\mathrm{H}_{2} \mathrm{O}\end{array}$ & $\begin{array}{l}2 \\
1\end{array}$ \\
\hline 12 & LASL- U [7] & $\begin{array}{l}\mathrm{T} \\
\mathrm{T} \\
\mathrm{T}\end{array}$ & $\begin{array}{l}25 \\
250 \\
700\end{array}$ & $\begin{array}{l}3 \mathrm{CO}_{2}+\mathrm{U}_{3} \mathrm{O}_{8}+\mathrm{H}_{2} \mathrm{O}=3 \mathrm{UO}_{2} \mathrm{CO}_{3}+\mathrm{H}_{2}(\mathrm{~g}) \\
3 \mathrm{UO}_{2} \mathrm{CO}_{3}=3 \mathrm{CO}_{2}(\mathrm{~g})+3 \mathrm{UO}_{3} \\
6 \mathrm{UO}_{3}(\mathrm{~s})=2 \mathrm{U}_{3} \mathrm{O}_{8}(\mathrm{~s})+\mathrm{O}_{2}(\mathrm{~g})\end{array}$ & $\begin{array}{l}1 \\
1 \\
1 / 2\end{array}$ \\
\hline 13 & Ispra Mark 8 [5] & $\begin{array}{l}\mathrm{T} \\
\mathrm{T} \\
\mathrm{T}\end{array}$ & $\begin{array}{l}700 \\
900 \\
100\end{array}$ & $\begin{array}{l}3 \mathrm{MnCl}_{2}+4 \mathrm{H}_{2} \mathrm{O}=\mathrm{Mn}_{3} \mathrm{O}_{4}+6 \mathrm{HCl}+\mathrm{H}_{2}(\mathrm{~g}) \\
3 \mathrm{MnO}_{2}=\mathrm{Mn}_{3} \mathrm{O}_{4}+\mathrm{O}_{2}(\mathrm{~g}) \\
4 \mathrm{HCl}+\mathrm{Mn}_{3} \mathrm{O}_{4}=2 \mathrm{MnCl}_{2}(\mathrm{a})+\mathrm{MnO}_{2}+2 \mathrm{H}_{2} \mathrm{O}\end{array}$ & $\begin{array}{l}1 \\
1 / 2 \\
3 / 2\end{array}$ \\
\hline 14 & Ispra Mark 6 [5] & $\begin{array}{l}\mathrm{T} \\
\mathrm{T} \\
\mathrm{T} \\
\mathrm{T}\end{array}$ & $\begin{array}{l}850 \\
170 \\
700 \\
420\end{array}$ & $\begin{array}{l}2 \mathrm{Cl}_{2}(\mathrm{~g})+2 \mathrm{H}_{2} \mathrm{O}(\mathrm{g})=4 \mathrm{HCl}(\mathrm{g})+\mathrm{O}_{2}(\mathrm{~g}) \\
2 \mathrm{CrCl}_{2}+2 \mathrm{HCl}=2 \mathrm{CrCl}_{3}+\mathrm{H}_{2}(\mathrm{~g}) \\
2 \mathrm{CrCl}_{3}+2 \mathrm{FeCl}_{2}=2 \mathrm{CrCl}_{2}+2 \mathrm{FeCl}_{3} \\
2 \mathrm{FeCl}_{3}=\mathrm{Cl}_{2}(\mathrm{~g})+2 \mathrm{FeCl}_{2}\end{array}$ & $\begin{array}{c}1 / 2 \\
1 \\
1 \\
1\end{array}$ \\
\hline
\end{tabular}


TABLE 6 (Continued)

REACTION DETAILS FOR CYCLES

\begin{tabular}{|c|c|c|c|c|c|}
\hline Cycle & Name & $\mathrm{T} / \mathrm{E}^{*}$ & $\mathrm{~T}^{\circ} \mathrm{C}$ & Reaction & $F^{\dagger}$ \\
\hline 15 & Ispra Mark 4 [5] & $\begin{array}{l}\mathrm{T} \\
\mathrm{T} \\
\mathrm{T} \\
\mathrm{T}\end{array}$ & $\begin{array}{l}850 \\
100 \\
420 \\
800\end{array}$ & $\begin{array}{l}2 \mathrm{Cl}_{2}(\mathrm{~g})+2 \mathrm{H}_{2} \mathrm{O}(\mathrm{g})=4 \mathrm{HCl}(\mathrm{g})+\mathrm{O}_{2}(\mathrm{~g}) \\
2 \mathrm{FeCl}_{2}+2 \mathrm{HCl}+\mathrm{S}=2 \mathrm{FeCl}_{3}+\mathrm{H}_{2} \mathrm{~S} \\
2 \mathrm{FeCl}_{3}=\mathrm{Cl}_{2}(\mathrm{~g})+2 \mathrm{FeCl}_{2} \\
\mathrm{H}_{2} \mathrm{~S}=\mathrm{S}+\mathrm{H}_{2}(\mathrm{~g})\end{array}$ & $\begin{array}{c}1 / 2 \\
1 \\
1 \\
1\end{array}$ \\
\hline 16 & Ispra Mark 3 [5] & $\begin{array}{l}\mathrm{T} \\
\mathrm{T} \\
\mathrm{T}\end{array}$ & $\begin{array}{l}850 \\
170 \\
200\end{array}$ & $\begin{array}{l}2 \mathrm{Cl}_{2}(\mathrm{~g})+2 \mathrm{H}_{2} \mathrm{O}(\mathrm{g})=4 \mathrm{HCl}(\mathrm{g})+\mathrm{O}_{2}(\mathrm{~g}) \\
2 \mathrm{VOCl}_{2}+2 \mathrm{HCl}=2 \mathrm{VOCl}_{3}+\mathrm{H}_{2}(\mathrm{~g}) \\
2 \mathrm{VOCl}_{3}=\mathrm{Cl}_{2}(\mathrm{~g})+2 \mathrm{VOCl}_{2}\end{array}$ & $\begin{array}{c}1 / 2 \\
1 \\
1\end{array}$ \\
\hline 17 & Ispra Mark 2 (1972) [5] & $\begin{array}{l}\mathrm{T} \\
\mathrm{T} \\
\mathrm{T}\end{array}$ & $\begin{array}{l}100 \\
487 \\
800\end{array}$ & $\begin{array}{l}\mathrm{Na}_{2} \mathrm{O} \cdot \mathrm{MnO}_{2}+\mathrm{H}_{2} \mathrm{O}=2 \mathrm{NaOH}(\mathrm{a})+\mathrm{MnO}_{2} \\
4 \mathrm{MnO}_{2}(\mathrm{~s})=2 \mathrm{Mn}_{2} \mathrm{O}_{3}(\mathrm{~s})+\mathrm{O}_{2}(\mathrm{~g}) \\
\mathrm{Mn}_{2} \mathrm{O}_{3}+4 \mathrm{NaOH}=2 \mathrm{Na}_{2} \mathrm{O} \cdot \mathrm{MnO}_{2}+\mathrm{H}_{2}(\mathrm{~g})+\mathrm{H}_{2} \mathrm{O}\end{array}$ & $\begin{array}{c}2 \\
1 / 2 \\
1\end{array}$ \\
\hline 18 & Ispra CO/Mn3O4 [10] & $\begin{array}{l}\mathrm{T} \\
\mathrm{T} \\
\mathrm{T}\end{array}$ & $\begin{array}{l}977 \\
700 \\
700\end{array}$ & $\begin{array}{l}6 \mathrm{Mn}_{2} \mathrm{O}_{3}=4 \mathrm{Mn}_{3} \mathrm{O}_{4}+\mathrm{O}_{2}(\mathrm{~g}) \\
\mathrm{C}(\mathrm{s})+\mathrm{H}_{2} \mathrm{O}(\mathrm{g})=\mathrm{CO}(\mathrm{g})+\mathrm{H}_{2}(\mathrm{~g}) \\
\mathrm{CO}(\mathrm{g})+2 \mathrm{Mn}_{3} \mathrm{O}_{4}=\mathrm{C}+3 \mathrm{Mn}_{2} \mathrm{O}_{3}\end{array}$ & $\begin{array}{c}1 / 2 \\
1 \\
1\end{array}$ \\
\hline 19 & Ispra Mark 7B [5] & $\begin{array}{l}\mathrm{T} \\
\mathrm{T} \\
\mathrm{T} \\
\mathrm{T} \\
\mathrm{T}\end{array}$ & $\begin{array}{l}1000 \\
420 \\
650 \\
350 \\
400\end{array}$ & $\begin{array}{l}2 \mathrm{Fe}_{2} \mathrm{O}_{3}+6 \mathrm{Cl}_{2}(\mathrm{~g})=4 \mathrm{FeCl}_{3}+3 \mathrm{O}_{2}(\mathrm{~g}) \\
2 \mathrm{FeCl}_{3}=\mathrm{Cl}_{2}(\mathrm{~g})+2 \mathrm{FeCl}_{2} \\
3 \mathrm{FeCl}_{2}+4 \mathrm{H}_{2} \mathrm{O}=\mathrm{Fe}_{3} \mathrm{O}_{4}+6 \mathrm{HCl}+\mathrm{H}_{2}(\mathrm{~g}) \\
4 \mathrm{Fe}_{3} \mathrm{O}_{4}+\mathrm{O}_{2}(\mathrm{~g})=6 \mathrm{Fe}_{2} \mathrm{O}_{3} \\
4 \mathrm{HCl}+\mathrm{O}_{2}(\mathrm{~g})=2 \mathrm{Cl}_{2}(\mathrm{~g})+2 \mathrm{H}_{2} \mathrm{O}\end{array}$ & $\begin{array}{l}3 / 4 \\
3 / 2 \\
1 \\
1 / 4 \\
3 / 2\end{array}$ \\
\hline 20 & Vanadium Chloride [11] & $\begin{array}{l}\mathrm{T} \\
\mathrm{T} \\
\mathrm{T} \\
\mathrm{T}\end{array}$ & $\begin{array}{c}850 \\
25 \\
700 \\
25\end{array}$ & $\begin{array}{l}2 \mathrm{Cl}_{2}(\mathrm{~g})+2 \mathrm{H}_{2} \mathrm{O}(\mathrm{g})=4 \mathrm{HCl}(\mathrm{g})+\mathrm{O}_{2}(\mathrm{~g}) \\
2 \mathrm{HCl}+2 \mathrm{VCl}_{2}=2 \mathrm{VCl}_{3}+\mathrm{H}_{2}(\mathrm{~g}) \\
2 \mathrm{VCl}_{3}=\mathrm{VCl}_{4}+\mathrm{VCl}_{2} \\
2 \mathrm{VCl}_{4}=\mathrm{Cl}_{2}(\mathrm{~g})+2 \mathrm{VCl}_{3}\end{array}$ & $\begin{array}{l}1 / 2 \\
1 \\
2 \\
1\end{array}$ \\
\hline 21 & Mark 7A [5] & $\begin{array}{l}\mathrm{T} \\
\mathrm{T} \\
\mathrm{T} \\
\mathrm{T} \\
\mathrm{T}\end{array}$ & $\begin{array}{c}420 \\
650 \\
350 \\
1000 \\
120\end{array}$ & $\begin{array}{l}2 \mathrm{FeCl}_{3}(\mathrm{l})=\mathrm{Cl}_{2}(\mathrm{~g})+2 \mathrm{FeCl}_{2} \\
3 \mathrm{FeCl}_{2}+4 \mathrm{H}_{2} \mathrm{O}(\mathrm{g})=\mathrm{Fe}_{3} \mathrm{O}_{4}+6 \mathrm{HCl}(\mathrm{g})+\mathrm{H}_{2}(\mathrm{~g}) \\
4 \mathrm{Fe}_{3} \mathrm{O}_{4}+\mathrm{O}_{2}(\mathrm{~g})=6 \mathrm{Fe}_{2} \mathrm{O}_{3} \\
6 \mathrm{Cl}_{2}(\mathrm{~g})+2 \mathrm{Fe}_{2} \mathrm{O}_{3}=4 \mathrm{FeCl}_{3}(\mathrm{~g})+3 \mathrm{O}_{2}(\mathrm{~g}) \\
\mathrm{Fe}_{2} \mathrm{O}_{3}+6 \mathrm{HCl}(\mathrm{a})=2 \mathrm{FeCl}_{3}(\mathrm{a})+3 \mathrm{H}_{2} \mathrm{O}(\mathrm{l})\end{array}$ & $\begin{array}{l}3 / 2 \\
1 \\
1 / 4 \\
1 / 4 \\
1\end{array}$ \\
\hline 22 & GA Cycle $23[12]$ & $\begin{array}{l}\mathrm{T} \\
\mathrm{T} \\
\mathrm{T} \\
\mathrm{T} \\
\mathrm{T}\end{array}$ & $\begin{array}{l}800 \\
850 \\
700 \\
25 \\
25\end{array}$ & $\begin{array}{l}\mathrm{H}_{2} \mathrm{~S}(\mathrm{~g})=\mathrm{S}(\mathrm{g})+\mathrm{H}_{2}(\mathrm{~g}) \\
2 \mathrm{H}_{2} \mathrm{SO}_{4}(\mathrm{~g})=2 \mathrm{SO}_{2}(\mathrm{~g})+2 \mathrm{H}_{2} \mathrm{O}(\mathrm{g})+\mathrm{O}_{2}(\mathrm{~g}) \\
3 \mathrm{~S}+2 \mathrm{H}_{2} \mathrm{O}(\mathrm{g})=2 \mathrm{H}_{2} \mathrm{~S}(\mathrm{~g})+\mathrm{SO}_{2}(\mathrm{~g}) \\
3 \mathrm{SO}_{2}(\mathrm{~g})+2 \mathrm{H}_{2} \mathrm{O}(\mathrm{l})=2 \mathrm{H}_{2} \mathrm{SO}_{4}(\mathrm{~g})+\mathrm{S} \\
\mathrm{S}(\mathrm{g})+\mathrm{O}_{2}(\mathrm{~g})=\mathrm{SO}_{2}(\mathrm{~g})\end{array}$ & $\begin{array}{l}1 \\
1 / 2 \\
1 / 2 \\
1 / 2\end{array}$ \\
\hline 23 & US -Chlorine [7] & $\begin{array}{l}\mathrm{T} \\
\mathrm{T} \\
\mathrm{T}\end{array}$ & $\begin{array}{l}850 \\
200 \\
500\end{array}$ & $\begin{array}{l}2 \mathrm{Cl}_{2}(\mathrm{~g})+2 \mathrm{H}_{2} \mathrm{O}(\mathrm{g})=4 \mathrm{HCl}(\mathrm{g})+\mathrm{O}_{2}(\mathrm{~g}) \\
2 \mathrm{CuCl}+2 \mathrm{HCl}=2 \mathrm{CuCl}_{2}+\mathrm{H}_{2}(\mathrm{~g}) \\
2 \mathrm{CuCl}_{2}=2 \mathrm{CuCl}+\mathrm{Cl}_{2}(\mathrm{~g})\end{array}$ & $\begin{array}{l}1 / 2 \\
1 \\
1\end{array}$ \\
\hline 24 & Ispra Mark 9 [5] & $\begin{array}{l}\mathrm{T} \\
\mathrm{T} \\
\mathrm{T}\end{array}$ & $\begin{array}{l}420 \\
150 \\
650\end{array}$ & $\begin{array}{l}2 \mathrm{FeCl}_{3}=\mathrm{Cl}_{2}(\mathrm{~g})+2 \mathrm{FeCl}_{2} \\
3 \mathrm{Cl}_{2}(\mathrm{~g})+2 \mathrm{Fe}_{3} \mathrm{O}_{4}+12 \mathrm{HCl}=6 \mathrm{FeCl}_{3}+6 \mathrm{H}_{2} \mathrm{O}+ \\
\mathrm{O}_{2}(\mathrm{~g}) \\
3 \mathrm{FeCl}_{2}+4 \mathrm{H}_{2} \mathrm{O}=\mathrm{Fe}_{3} \mathrm{O}_{4}+6 \mathrm{HCl}+\mathrm{H}_{2}(\mathrm{~g})\end{array}$ & $\begin{array}{l}3 / 2 \\
1 / 2\end{array}$ \\
\hline 25 & Ispra Mark 6C [5] & $\begin{array}{l}\mathrm{T} \\
\mathrm{T} \\
\mathrm{T} \\
\mathrm{T}\end{array}$ & $\begin{array}{l}850 \\
170 \\
700 \\
500\end{array}$ & $\begin{array}{l}2 \mathrm{Cl}_{2}(\mathrm{~g})+2 \mathrm{H}_{2} \mathrm{O}(\mathrm{g})=4 \mathrm{HCl}(\mathrm{g})+\mathrm{O}_{2}(\mathrm{~g}) \\
2 \mathrm{CrCl}_{2}+2 \mathrm{HCl}=2 \mathrm{CrCl}_{3}+\mathrm{H}_{2}(\mathrm{~g}) \\
2 \mathrm{CrCl}_{3}+2 \mathrm{FeCl} \\
2 \mathrm{CuCl}_{2}=2 \mathrm{CuCl}+\mathrm{Cl}_{2}(\mathrm{~g})\end{array}$ & $\begin{array}{l}1 / 2 \\
1 \\
1 \\
1\end{array}$ \\
\hline
\end{tabular}

${ }^{*} \mathrm{~T}=$ thermochemical, $\mathrm{E}=$ electrochemical.

$T_{\text {Reactions are stored in database with minimum integer coefficients. Multiplier from reaction junction table converts }}$ the results to the basis of one mole of water decomposed. 


\section{REFERENCES}

[1] EndNote 3.1.2, ISI Research Soft, Berkeley, California (1999).

[2] HSC Chemistry 4.0, Outokumpu research Oy, Pori, Finland (1999).

[3] Yoshida, K., H. Kameyama, et al., "A simulation study of the UT-3 thermochemical hydrogen production process," Int. J. Hydrogen Energy 15 (1990) 171-178.

[4] Brecher, L.E., S. Spewock, et al., "Westinghouse sulfur cycle for the thermochemical decomposition of water," Int. J. Hydrogen Energy 21 (1977) $7-15$

[5] Beghi, G.E., "A decade of research on thermochemical hydrogen at the joint research center, Ispra,” Int. J. Hydrogen Energy 11 (1986) 761-771.

[6] Besenbruch, G.E., "General Atomic sulfur-iodine thermochemical water-splitting process," Am. Chem. Soc., Div. Pet. Chem., Prepr. 271 (1982) 48-53.

[7] Williams, L.O., "Hydrogen Power," Pergamon Press (1980).

[8] Ueda, R., H. Tagawa, et al., "Production of hydrogen from water using nuclear energy," A review, Japan At. Energy Res. Inst., Tokyo, Japan. (1974) 69.

[9] Tamaura, Y., A. Steinfeld, et al., "Production of solar hydrogen by a novel, 2-step, water-splitting thermochemical cycle," Energy (Oxford) 20 (1995) 325-330.

[10] Bamberger, C.E., "Hydrogen production from water by thermochemical cycles; a 1977 update," Cryogenics 18 (1978) 170-183.

[11] Knoche, K.F. and P. Schuster, "Thermochemical production of hydrogen by a vanadium/chlorine cycle. Part 1: An energy and exergy analysis of the process," Int. J. Hydrogen Energy 9 (1984) 457-472.

[12] Russell, J., Porter, J., "Production of hydrogen from water," General Atomics Report GA-A12889 (1974). 


\section{ACKNOWLEDGMENTS}

This is a report of work supported by the Nuclear Energy Research Institute (NERI) under Grant No. DE-FG03-99SF21888 and the U.S. Department of Energy under Contract No. DE-AC04-94AL85000 with Sandia National Laboratory, a multiprogram laboratory operated by Sandia Corporation, a Lockheed Martin Company. 